\title{
Reflections on Macron's Proposals for a Renewed EU
}

\section{Reflexiones sobre las propuestas de Macron para la renovación de la UE}

\author{
Ariane Bogain ${ }^{1}$ \\ University of Northumbria, Newcastle (England)
}

Recibido: 14-09-20

Aceptado: 26-09-20

\begin{abstract}
Emmanuel Macron, elected French President on a pro-European platform against a staunchly Eurosceptic opponent in 2017, has sought to reinvigorate the European construction shaken by a decade of multiple crises. Whether lauded or vilified for being a passionate believer in the European project, he has laid out a comprehensive vision for the future of the EU through a series of key speeches. This article aims to discuss and assess Macron's contribution to the debate on the future of the EU. After outlining the global and EU context in which Macron has been operating, it argues that his vision, whilst comprehensive and offering avenues for pro-Europeans, contains a series of blind spots that undermines it and which needs to be tackled if the European project is to advance.
\end{abstract}

Palabras-clave: Emmanuel Macron, Future of the EU, Sovereignty, Democracy, Euroscepticism

1 (ariane.bogain@northumbria.ac.uk). Ariane Bogain is Senior lecturer in French and Politics in the Department of Social Sciences. She has taught French and European politics since 1997 at Northumbria University, first within the French department and subsequently within the Politics and International relations department. Her publications include the following: Bogain, A. (2019). Terrorism and the discursive construction of national identity in France. "National Identity", 21 (3); Bogain, A. (2017). Security in the name of human rights: the discursive legitimation strategies of the war on terror in France. "Critical Studies on Terrorism", 10 (3); Bogain, A. (2014). Demons, Ants, Giants and Dwarves: The Construction of Germany's Handling of the Euro Crisis in French Political Discourse. "Journal of Contemporary European Studies", 22 (1); Bogain, A. (2013). Jules Romains' Vision of a United Europe in Interwar France: Legacy and Ambiguities. "Modern \& Contemporary France", 21 (1).

ORCID: https://orcid.org/0000-0002-8274-9546. 


\section{Resumen}

Emmanuel Macron, elegido presidente francés en 2017 en una plataforma proeuropea contra un oponente acérrimamente euroescéptico, ha tratado revitalizar la construcción europea sacudida por una década de crisis múltiples. Ya se le alabe o vilipendie por ser un creyente apasionado del proyecto europeo, ha expuesto una visión integral del futuro de la UE a través de una serie de discursos clave. El presente artículo aspira a discutir y evaluar la contribución de Macron al debate sobre el futuro de la UE. Tras esbozar el contexto global y de la UE en el que Macron ha operado, argumenta que su visión, integral y que ofrece vías para los proeuropeos, contiene una serie de puntos ciegos que la socavan y tienen que replantearse si el proyecto europeo ha de seguir adelante.

Key-words: Emmanuel Macron, futuro de la UE, soberanía, democracia, euroescepticismo.

\section{Introduction}

In 2016, Jean-Claude Juncker, the former President of the EU commission, declared in his State of the Union address that "our European Union is, at least in part, in an existential crisis" (Juncker 2016: 6). He might have qualified his statement but the succession of acute crises the EU has had to face over the past decade has led politicians, the media and scholars to discuss the real possibility of disintegration (for example Jones 2018). Battered by the Euro crisis, the refugee crisis, Brexit, the rule of law crisis, the rise of illiberalism, Euroscepticism and anti-EU populist parties, "the EU has glimpsed its own mortality" (Hodson and Puetter 2018: 466). Whilst still grappling with their legacy, it is now facing not only a changing external environment with the return of big power politics and the erosion of multilateralism but also a pandemic that Angela Merkel called the biggest test facing the EU. With a significant death toll and ravaged economies, Covid-19 has reignited talks of existential crisis for the EU. Despite the recovery plan, agreed in July 2020 that created financial transfers for the first time, heralded by many as a historic breakthrough towards solidarity between Member States, the economic and social fallouts of the pandemic is adding pressure on an organisation already riven with divisions on key issues like migration, the Eurozone, the rule of law and most importantly the future (Dinan 2019).

The EU is aware of its vulnerability, as evidenced by the EU commission's "white paper on the future of Europe" in 2017 (EU Commission) and the ensuing debates at the Rome summit in March 2017. At around the same time, 
the French presidential campaign pitted an avowedly pro-European candidate, Emmanuel Macron, against the staunchly Eurosceptic Marine Le Pen. Framing the contest as a battle between cosmopolitanism versus nationalism, he sought to anchor France at the heart of the EU against Le Pen's nationalist vision. Once elected, the new President set his vision for the future of the EU in a series of speeches, most notably in Athens and at the Sorbonne University in September 2017. They laid down his philosophy and proposals, which he would expand upon in numerous subsequent speeches and interviews.

This article aims to discuss Macron's contribution to the debate on the future of the EU. First, it will outline the global and EU context in which he has been operating, then it will analyse the philosophy underpinning his vision before assessing the significance of his contribution from a pro-European lens, as is the theme of this special edition. This contribution argues that his vision, whilst comprehensive, ambitious and offering concrete solutions to the multiple issues the EU is facing, contains a series of blind spots that undermines it and from which lessons have to be drawn.

\section{The Global context}

The EU is facing an external environment under increasing stress. With the US fast retrenching from multilateralism under President Trump, the post WW2 liberal order is under assault from its own architect (Jervis et al. 2018), as evidenced by the US retreating from international organisations (WHO, UNESCO, UNRWA), withdrawing from multilateral treaties (the Paris climate accord, the Iran deal, the Trans-Pacific partnership), criticising multilateral organisations like the UN or NATO, and privileging bilateral relationships to wield its power unencumbered. The EU, so used to a hegemon that "was sympathetic towards European integration" (Fägersten and Von Sydow 2019:10), is now facing an American President full of hostility. With Trump accusing the European project of having been set up against the USA, and threatening the future of NATO, the traditional reliance on the American ally can no longer be taken for granted. The collective security of Europe wielded to a trans-Atlantic alliance has become increasingly questioned, leaving the EU with hard choices on security and defence.

At the same time, the de facto hegemony the US has enjoyed since the $90 \mathrm{~s}$ is being increasingly challenged, which creates its own sets of issues for the EU. The rise of China as a global power has long been charted, as has the emergence of challengers, whether it is Russia, India, Brazil, or Turkey. Opinion differs as to whether the international system is moving towards a new bipolarity (Allison 2017) pitting the US against China, multipolarity (Kupchan 1998), or multi- 
order (Flockhart 2016). However, the challenge to US hegemony is reshaping the world the EU had grown accustomed to and is putting it face to face to great power rivalry and zero-sum thinking, with covid-19 further heightening tension and eroding multilateralism (Puglierin and Franke 2020b). The EU might be keen to promote a resilient rules-based multilateral system (European Council 2019) but it is now facing "a world in which power is becoming more important as a currency, $[\ldots]$ and in which complex moral choices return to the forefront of strategic and diplomatic decisions." (Martill and Brinke 2020: 5)

The situation closer to the EU offers no comfort. In the East, the renewed assertiveness of Russia over the past decade remains an important issue for the EU. The strategic partnership, launched in 2003 turned into competition, culminating in the Ukraine crisis and the annexation of Crimea. Since then, the conflict has become frozen, and the relationship remains deeply acrimonious. In the South-East, Turkey has emerged as a challenge, with its interventions in Libya, Syria and more recently the Eastern Mediterranean perceived as a security risk for the EU, and threatening the cohesion of NATO. And then there is Brexit. It certainly represented a setback for the European project, but it has not heralded, so far, the break-up of the Union. In strategic terms, the EU does lose a big player but the damage is not insurmountable as long as NATO remains the primary actor (Svendsen 2019). Britain's departure can even offer new opportunities as it has traditionally opposed integration in foreign policy and defence (Martill and Brinke 2020). This can be illustrated by the successful launch of a Permanent Structured Cooperation (PESCO) in 2017. However, internally, the balance of power has been disrupted. The more market-oriented Member States have lost a powerful ally and a rebalancing against Germany's perceived ascendency looks inevitable, whether towards France, a renewed Franco-German partnership, or towards a coalition of mini-blocks.

The American withdrawal, the rise of China, Russia's assertiveness and an increasingly unstable world of power politics has worsened the collective security of the EU and is forcing it to find a place in global politics in order to shape its future. However, with the EU continuing "to face the internal challenge of forging consensus and common positions within the CFSP [Common Foreign and Security Policy] and encouraging greater defence collaboration within the CSDP [Common Security and Defence Policy]" (Kenealy 2019:123) it is increasingly facing hard choices.

\section{The EU context}

The multiple crises that have affected the EU since the rejection of the European constitution in 2005 by two of its founding members, France and 
the Netherlands, are well-known and well documented. The intricacy of each crisis is beyond the scope of this article, but their overall impact is important to highlight as they have shaped the current context the EU finds itself in.

For decades, the European project was based on a "permissive consensus", whereby integration was deepened without much public scrutiny or concern (Lindberg and Sheingold 1970). With the creation of the EU and the move towards deeper integration into core areas of state sovereignty like monetary power, this consensus has increasingly given way to a legitimation challenge (Hooghe and Marks 2009). This is because the consequences of European integration have become not only much more visible but also turned increasingly negative through the succession of crises the EU endured.The Euro crisis provides a good illustration of the legitimation challenge facing the EU. The European Central Bank might have avoided the implosion of the Eurozone but its consequences in terms of unemployment, real wages falling, and austerity policies led to anger, anxiety and disillusion with the European project, spilling into hostility amongst public opinion (Braun and Tausendpfund 2014). In addition, the bailouts agreed in the form of loans in exchange of structural reforms, instead of fiscal transfers, has led to the EMU being perceived as a "vehicle for imposing market discipline on member states" (Kundnani 2018), and the EU as a punishing organisation. This has led to feelings of democratic unaccountability both at the EU and national level, as well as deep resentment between Member States, creating an entrenched rift between creditor and debtor countries (Armingeon et al. 2016).

With people feeling the effects of integration more and more in their lives, opposition to the EU has grown (Hutter and Kriesi 2019) and new cleavages have appeared. EU scholars have used different labels to refer to them such as "integration-demarcation", "universalism-communitarianism", "cosmopolitanismcommunitarianism", "cosmopolitanism-parochialism", or 'transnational cleavage' (see Hutter and Kriesi 2019). Irrespective of the labels, they all stress how cleavages pitting citizens whose vision is more open, universalist, liberal and cosmopolitan against those with more closed, communitarian, and nationalist orientations, put an end to the permissive consensus. Populist parties have been decisive in this regard. On the right, they have been mobilising citizens with exclusive identities and tapping into a sense of anxiety heightened by the EU's polycrisis. On the left, they have focused on the consequences of this crisis on inequality and poverty. The polycrisis therefore acted as a trigger that led to a dramatic change in party alignment across Europe, with the rise of populist, Eurosceptic, anti-Euro and antiEU parties squeezing mainstream parties. The significant drop in confidence in both national governments and the EU in Eurobarometers surveys at the height of the Euro-crisis illustrates how the populist message of out-of-touch elite has struck a chord. These parties have succeeded in negatively politicisising what used 
to be "a depoliticised, technocratic and multilateral polity" (De Wilde and Lord 2016:145). They have driven a politicisation process "through which European integration has become the subject of public discussion, debate and contestation" (Schmidt 2019a: 1018). As opponents of European integration have led and framed the debate (Schmidt 2019a), increasing levels of polarisation in opinion about the $\mathrm{EU}$ and increasing mobilisation of actors giving voice to discontent have further undermined the permissive consensus.

Whereas the two traditional theories of European integration, NeoFunctionalism and Intergovernmentalism, see European integration as "an efficiency improving process" (Hooghe and Marks 2019:1116) in which actors are either pushed by functional pressures to integrate further or by a cost-benefit analysis, a more recent theory, Post-Functionalism, has stressed how disruptive the clash between functional pressures and negative politicisation is for the EU (Hooghe and Marks 2019). Thus, the last decade has shown how mobilisation of exclusive identities by radical right parties has hampered further integration because governments, feeling their pressure at the domestic level, have increasingly challenged the EU's rules and norms (Vollaard 2018) and adopted a harder stance in negotiating new decisions in order defend themselves against accusations of giving away national sovereignty. This "constraining dissensus" weighing on EU governments (Hooghe and Marks 2019) has restricted their ability to act, leading to "a mismatch of functionally efficient and politically feasible solutions" (Hooghe and Marks, 2009: 23). This has created a "politics trap" (Zeitlin et al. 2019), with national leaders at the EU level being inhibited from reaching the compromises needed to resolve urgent policy problems, leading to sub-optimal decisions, thereby further fuelling more diffidence against the EU.

The EU's polycrisis has also rekindled criticisms of a democratic deficit. The EU, like its predecessor, has privileged output legitimacy, i.e. successful policy-making leading to beneficial outcomes, rather than input legitimacy, i.e. when citizens can not only inform decisions but also contest and radically change the overall direction of a polity (Scharpf 1999). However, whilst relying on output legitimacy was not a problem when integration was dealing with non-redistributive functions, it became so with the integration of core functions and ensuing issues of redistribution (Majone 2014). It turned into an even bigger issue when the EU's ability to bring positive outcomes became under strain due to the economic and social fallouts of the Euro-crisis. Thus, as Scharpf argued (2013), this crisis weakened output legitimacy and therefore allegiance to the EU because it could not deliver prosperity and well-being to its citizens. The weakening output legitimacy could be compensated by input legitimacy, but critics, using a variation of Føllesdal and Hix's 5 democratic criteria (2006), argue that a democratic deficit prevents the EU from fostering 
it: (1) EU powers are "beyond the control of national parliaments" (535); (2) The European Parliament remains too weak; (3) No genuine electoral contest exists because EU citizens cannot vote for radically different directions of travel for the EU due to the treaties determining and constraining what the EU can and cannot do; (4) The EU is psychologically and institutionally removed from citizens; (5) EU decisions deviate from "voters' ideal policy preferences" (537) as they are constrained by EU treaties. It is true that some scholars deny the existence of a democratic deficit. Moravcsik, for example, argues that an international organisation like the EU should not be compared with an idealised model of deliberative democracy (2002: 606). The EU is not a state and should therefore not be judged according to democratic norms that apply to states. In addition, decisions are taken by democratically elected governments and MEPs. Irrespective of who is right, the idea of a democratic deficit has cut through amongst public opinion, as seen during the Brexit referendum, and has become the thorniest of issues for the EU.

Indeed, the idea of democratising the EU is facing two major issues. First, a deep paradox lies at its heart. Democratic deficit implies that the EU is at fault, that it has confiscated powers from citizens. And yet, its architecture flows from choices "made expressly and repeatedly by the member states over time as to the institutional structure for decision-making they are willing to accept" (Craig, 2019: 312). These choices could have been different, citizens could have been involved more but states chose not to. The EU is not exterior to or against states, states are in control and have decided how it should work. It would be perfectly possible to create a parliamentary majoritarian regime, for example, but states do not want their powers to be reduced. With states unwilling to part with their powers, tackling input legitimacy becomes politically very complicated, which further undermines the Union. Second, any input legitimacy needs a clear understanding of what EU democracy would mean. However, conflicting notions of democracy, underpinned by different articulations of a statist versus a non-statist conception of sovereignty on the one hand and the existence of a European demos or not on the other, has led to a normative battle (Beetz 2019). Thus, some put forward national popular sovereignty, based on rejecting the existence of a European demos and linking sovereignty to the existence of a state. As a result, the EU should be wholly intergovernmental, with a veto for each state as they are the true sovereigns. Proponents of European popular sovereignty, on the other hand, share the statist conception but believe in the existence of a European demos. The EU should therefore become a state representing this demos directly, with national states becoming sub-level entities. Others believe in simultaneous popular sovereignty, which combines a European demos with a non-statist conception of sovereignty. Sovereignty should therefore be split between national peoples 
and EU citizens, for example through one parliament for states and one for people. Others favoured shared popular sovereignty, which constructs the EU as a demoicracy, combining a rejection of a European demos with a nonstatist conception of sovereignty based on empowering national peoples at the EU level, for example through national parliaments rather than executives representing citizens at the EU level. The key challenge for the EU is to make a normative choice to legitimate Europe's governance system, as these conceptions lead to institutional proposals conflicting with one another. As Beetz argues, until a decision is made and approved by citizens, "conflicts about the appropriate conception of popular sovereignty are likely to continue to challenge the stability of the European Union" (2019: 949).

Mearsheimer famously predicted the collapse of the European project after the Cold War and a return to traditional rivalry between Member States (1994). He might yet be proven right unless the EU tackles the numerous challenges outlined above. The EU is not a stable polity. Facing uncertainty stemming from "tensions between the national and the European, between the EU and its wider global environment, between unity and deep diversity, and between different modes of political economy and levels of development" (Laffan 2019), it is now at a cross-road. It may have proved resilient during its polycrisis and it has succeeded in muddling through but the challenges the EU faces cannot be fixed by short-term solutions taken under pressure in the middle of a crisis. In view of this context, what can be made of Macron's contribution to the future of the EU?

\section{Macron's vision for the future of the EU.}

After a decade when Member States were trapped in everyday crisis management, Macron has offered an impassioned plea for the EU, articulating a positive framing of the European project and radically breaking away from his predecessor's polite indifference towards the EU (Chopin 2018). The scope of his proposals is undeniably ambitious, as summarised in the table below. 
Table 1 - Macron's proposals

\begin{tabular}{|c|c|}
\hline Themes & Key proposals \\
\hline Europe as a balancing power & $\begin{array}{l}\text { European sovereignty } \\
\text { Obtaining military credibility }\end{array}$ \\
\hline Eurozone & $\begin{array}{l}\text { Common budget } \\
\text { Finance Minister } \\
\text { Eurozone parliament } \\
\text { Fiscal union }\end{array}$ \\
\hline Security and defence & $\begin{array}{l}\text { Common intervention force } \\
\text { Common funds } \\
\text { Enhanced cooperations } \\
\text { Common strategic culture } \\
\text { Cooperation between intelligence services } \\
\text { European intelligence academy } \\
\text { European civil protection force to respond to di- } \\
\text { sasters } \\
\text { Cybersecurity } \\
\text { European public prosecutor's office for organised } \\
\text { crime and terrorism }\end{array}$ \\
\hline Border & $\begin{array}{l}\text { European asylum authority and border police } \\
\text { Programme for training and integration of } \\
\text { refugees } \\
\text { External aid funded by financial tax } \\
\text { Partnership with Africa } \\
\text { Reform Schengen with strict control of external } \\
\text { borders and same asylum policy }\end{array}$ \\
\hline Climate & $\begin{array}{l}\text { Green deal } \\
\text { External Carbon tax } \\
\text { Single energy market } \\
\text { Common price on carbon tax internally } \\
\text { Food security } \\
\text { New CAP } \\
\text { European agency to control food standards }\end{array}$ \\
\hline
\end{tabular}




\begin{tabular}{|c|c|}
\hline Digital & $\begin{array}{l}\text { Creating European champions } \\
\text { European agency for innovation } \\
\text { Single digital market } \\
\text { Digital tax } \\
\text { Copyright } \\
\text { Regulating large platforms }\end{array}$ \\
\hline Industrial policy & $\begin{array}{l}\text { Space policy } \\
\text { Fair competition rule from outside the single } \\
\text { market } \\
\text { European preference for public procurement } \\
\text { European prosecutor's office for trade standards. }\end{array}$ \\
\hline Social Europe & $\begin{array}{l}\text { New directive on detached workers } \\
\text { Social dialogue } \\
\text { Fight against social dumping } \\
\text { Social convergence } \\
\text { Renew social model }\end{array}$ \\
\hline Convergence & $\begin{array}{l}\text { Company taxation } \\
\text { Minimum wage } \\
\text { Payroll taxes }\end{array}$ \\
\hline Institutions & $\begin{array}{l}\text { Differentiated integration } \\
\text { Commission reduced to } 15 \\
\text { More transparency } \\
\text { Simplified norms } \\
\text { Quicker decision-making }\end{array}$ \\
\hline Culture & $\begin{array}{l}\text { Language policy } \\
\text { Increase student exchanges } \\
\text { Creation of European universities }\end{array}$ \\
\hline Democracy & $\begin{array}{l}\text { Citizens' conventions } \\
\text { Transnational lists } \\
\text { Defence of Human rights } \\
\text { European agency for the protection of democracy } \\
\text { Fight against hate speech } \\
\text { Conference on the future of Europe } \\
\text { Citizens at the heart of the EU }\end{array}$ \\
\hline
\end{tabular}


It is argued that these proposals are underpinned by the discursive construction of an "imagined community" (Anderson 1991) designed to bind EU citizens together. Considerable research has theorised the imaginary nature of collective identities, and has shown them to be a social construct, shaped and reproduced through discourse (for example Billig 1995). State authorities discursively create the notion of "the people" to whom they ascribe a common history and "systems of cultural representations" (Hall 1996). This is precisely what Macron's speeches seek to construct. Indeed, he delineated an imagined community bound together by a shared "fate" (Macron 2017a) with deep historical roots. When he talks about a "European civilisation" (Macron 2020a), and a "continent" in which "we, Europeans, share a history and a fate"(Macron 2017a) he seeks to create a collective entity that goes far beyond the current institutional framework. When he said, "whoever you are, whatever your age, your nationality and your origin, does the miracle of this hill [the Acropolis], the columns of the Parthenon, the silhouette of the Erechtheion and its caryatids not awaken in you the feeling that something was born here that concerns you, that belongs to you, that speaks to you?" (Macron 2017a), he constructed a grand narrative about Europe, linking the past to the present and the future, that binds the imagined community together. His choice of the Acropolis, the symbol of European democracy, as the setting for his first speech, is a performative act designed to further anchor the imagined community in a common civilisation, as are his numerous references to a common European culture, as epitomised by the following quote: "This Europe, where every European recognizes their destiny in the figures adorning a Greek temple or in Mona Lisa's smile, where they can feel European emotions in the writings of Musil or Proust, this Europe of cafés that Steiner described, [...] this Europe of landscapes and folklores" (Macron 2017b).

Creating collective identities always involve the construction of an "us" versus a "them" because, as Billig (1995) showed, a "self" is dependent on the creation of differences with an "other" and on ascribing qualities to "us" that "they" do not possess. This is what Macron engaged in, as his speeches are underpinned by the discursive construction of what "we" European are. "We" have unique values, we have "a foundation of values, rights and freedoms" (Macron 2020a) which includes freedom, equality, human rights, justice, social justice, cultural diversity, emancipation from religion, democracy (for example Macron 2017b, 2020a). Others might have them too but "what constructs and forges our profound identity, this balance of values, this relation with freedom, human rights and justice cannot be found anywhere on the planet." (Macron 2017b) The in-group of the imagined community is therefore defined in opposition to out-groups that do not share "our" values. Thus, the USA does not have the same relationship to equality, cultural diversity and pluralism as "we" 
do (Macron 2017b), and China does not share "our" relationship to freedom and equality (Macron 2017b). As a result, Macron can argue that "we are genuinely a singular continent and political power in our collective preferences and philosophical roots", thereby constructing a distinctive in-group bound together through their differences with out-groups.

This imagined community, however, is fragile because of the "loss of faith" in the European project (Macron 2017b). The second stage of Macron's vision therefore focuses on its causes in order to then provide his solutions. He apportioned the blame for the situation between the following: (1) output legitimacy, with citizens failing to see the benefits of the EU and feeling anxious about the future. Thus, citizens see the EU "as a project of injustice" (Macron 2020a), and as a "soulless market" (Macron 2019a). Thus, he explains Brexit by the EU's inability to respond to citizens' desire for protection (Macron 2017b). (2) Input legitimacy, with citizens feeling that "Europe is being made in spite of them" (in Chopin 2018: 4). (3) The internal working of the EU, which Macron characterised as no longer fit for purpose, as it is "too weak, too slow and too inefficient" (Macron 2017b). (4) Member States because they have fuelled anti-EU narratives by blaming Brussels for every issue they face, without explaining that the EU is what member states make of it (Macron 2019a, 2017b). (5) Pro-European forces for failing to challenge Euroscepticism and instead being cowed by it (Macron 2019a, 2017b).

Based on this assessment, his solution is to reclaim the politicisation process, wrenching it away from Eurosceptics, in order to tie his imagined community again to the EU through a change of narrative. When he criticised those who want to go slowly for fear of fuelling Euroscepticism and when he stated that "we cannot afford to do as we did in the past, refusing to talk about Europe, [...] and accusing Brussels or Strasbourg of being the source of all ills" (Macron 2018a), he clearly underpinned his vision on shifting perceptions of the EU. First, Macron sought to change the perception of sovereignty by debunking the notion of national sovereignty, which he characterised as an illusion (Macron 2017b). By using multiples examples designed to underline how Member States cannot resist "the new storms of globalisation" (Macron 2017b) alone, cannot tackle global challenges on their own, and even less stand up to the pressures exerted by big powers (Macron 2019b), he aimed to shift perception towards the necessity of a "European sovereignty". The following quote illustrates his strategy: "we need Europe for the ecological transition. We need Europe to feed ourselves, to face the big migratory, digital and technological transformations" (translated by the author, Macron 2020b). To further shift perceptions, he employed a strategy of dramatisation and sublimation. When he argues that Europe is becoming marginalised in the world (Macron 2019b), he not only dramatised the prospect of being ruled by 
outsiders if it is not sovereign ("not be subjected to the law of the fittest, the Americans and, soon, the Chinese, but our own law" (Macron 2017a)) but also the spectre of falling into oblivion (Europe "will disappear" unless it thinks "of itself as a global player" (Macron 2019b)). Sublimation is applied when, to counter Eurosceptic arguments about the loss of national sovereignty, he constructs European sovereignty as its enabler, as illustrated by his statement that "we need a sovereignty which is stronger than our own, which works alongside our own and does not replace it" (Macron 2018a).

Second, he sought to change perceptions by targeting diffuse support, i.e. the belief in the legitimacy of a political object (Easton 1975), in this case the European project. Breaking away from the negative and anxietyinducing narrative of constant crisis he seeks to re-create a forward-looking grand narrative for the EU. Hence, his call for the EU to lay down a 30-year vision (Macron 2018b) so that it offers a positive and clearly defined future, thereby resetting perceptions. However, it is clear that Macron is aware that specific support, i.e. the satisfaction in the economic and political performance of the political object (Easton 1975), which plummeted during the EU's polycrisis (Zeitlin et al. 2019), has to be activated too. His third strategy to shift perceptions, therefore, involves reconnecting citizens with the EU by focusing on both output and input legitimacy. When he says "we must listen to the anger of the European people today. They do not need lessons but a new project, a need for effectiveness on a daily basis" (Macron 2018a), he implies that the shift of perception will not occur unless the EU can offer concrete responses to the problems citizens are facing. This is why his concept of European sovereignty is underpinned by the necessity to enhance the EU's capacity to meet the needs of its citizens, whether it is their security, both internal and external, their economic and social well-being or their ability to deal with global phenomena such as climate change. Hence, his focus on a leaner and nimbler institutional framework to provide quicker outcomes, as well as his focus on forcefully promoting the concrete benefits the EU brings. Changing perceptions also needs input legitimacy, as illustrated by his focus on democracy, on creating "this public European space which we have so often neglected" (Macron 2018a) as well as his stress on creating a new social model so that the EU can be "give[n] back to European citizens" (Macron 2017b).

To conclude on Macron's vision, it is argued that he has sought to construct an imagined community, bound by shared history, values and culture, to whom a new narrative is offered in order to rekindle their belief in the EU, their current institutional incarnation. It can also be argued that he seeks to find bridges between what seems irreconcilable standpoints. Thus, European sovereignty as a sublimation of national sovereignty goes beyond nationalist and federalist tendencies. Thus, the imagined community he constructs is reconciled with 
concerns about surrendering national sovereignty. Thus, more integration is largely based on the creation of new agencies, which, as Egeberg showed, is a "political compromise between, on the one hand, the functional need for more regulatory capacity at European level and, on the other hand, member states' unwillingness to transfer more power to the Commission" (2015: 71). However, what does his vision bring to the debate on the future of the EU?

\section{Assessment}

Macron's impassioned plea for the EU and his comprehensive vision for its future have been characterised as one "of the major attempts from a European politician to reinvigorate the European project" (Navratil 2019:11). This ambition was recognised as such by many commentators and politicians across the EU. The Charlemagne prize board went as far as calling him a "courageous mastermind for the renewal of the European dream" (Euractiv 2018). However, how significant is Macron's contribution to the debate over the future of the EU? It is argued that though it does offer avenues for proEuropeans it also contains significant problems that they would need to tackle and overcome if the European project is to advance.

\section{A new narrative}

Much research has highlighted the importance of perception in politics. Forces opposed to the EU have been driving the narrative about the EU in the past decade, with pro-Europeans on the back foot, resorting to a large extent to depoliticisation to try and shield the EU from their influence (Schimmelfennig, 2019). Macron's importance lies in his determined attempt to change the narrative, to take the fight to Eurosceptic forces, and to break away from a decade of muddling through by putting forward instead a positive long-term vision, thereby offering a new dynamism to pro-Europeans. Macron offers a template to change the way the EU is framed by (1) providing a positive narrative; (2) focusing on the benefits the EU brings; (3) finding concrete solutions to the various woes facing the EU; (4) wrenching the politicisation process from Eurosceptics in order to drive the narrative; (5) talking about Europe instead of shying away from debates, which, as Schmidt (2019) shows, only fuels Euroscepticim further; (6) using Eurosceptic arguments and concepts from both the right and the left and making them compatible with the EU. Hence the importance of his concept of European sovereignty, which takes sovereignty away from nationalist forces and offers an answer to their key argument against the EU by infusing it with a different and positive meaning. Indeed, the "take 
back control" of Eurosceptics becomes nations taking back control through the EU. (7) Showing contrition for past mistakes, and acknowledging that the EU is far from perfect, as doing otherwise simply fuels accusations of not listening to citizens.

However, Macron's desire to change the narrative contains deeply problematic aspects. Macron's European sovereignty is based on providing protection and security from the outside world, as evidenced by his stress on secure borders, and on making the EU stronger to be able to provide a shield against hostile powers, the "storms of globalisation" as well as global challenges. By focusing so much on protection and security, he engaged in the creation of a series of dangerous others (migrants, hostile powers, global markets, global threats) against which the EU has to fight, which is reinforced by his construction of an exclusionary imagined community. The danger lies in constructing a deep-rooted fear of the other "as a source of insecurity and uncertainty" (Baker-Beall 2009: 190), which can easily turn into a securitisation process, whereby existential threats are created and these act "as a trigger to set off extraordinary measures" (Hellman et al., 2014, p.375). Research has already shown how this process is at play in EU policies such as counter-terrorism and immigration. The danger in Macron's vision is therefore an exacerbation of a politics of fear, which has been shown to be endemic in Western society for the past few decades (Baker-Beall 2009:189), through creating ontological insecurities for the EU. This can all too easily lead to a governmentality of unease (Bigo 2002), whereby fears of dangerous others are used by institutions, in this case the EU, "to affirm their role as providers of protection and security" (Bigo 2002: 65) and to put in place extraordinary measures.

Stressing security and protection for an imagined community can also easily play into the hands of Eurosceptic forces. Citizens might agree with the values of Macron's imagined community but that does not mean they are ready to accept more integration if they feel that these values are better catered for at the national level. Similarly, his europeanisation of Eurosceptics' concepts does not mean that citizens will agree that the EU level is the best to implement them. Marine Le Pen casting Macron as an agent of the globalised order "who no longer believes in France" (Bremner 2017) shows that Eurosceptic arguments will not be washed away simply by talking about a shared community or European sovereignty protecting citizens. The new narrative Macron is pushing for might therefore inflame Euroscepticism instead of quelling it, all the while constructing a deeply problematic anxiety-inducing vision of an EU fighting a series of dangerous others out there to destroy it. 


\section{Brilliant architect but poor brick layer}

Macron has received a lot of praise for his speeches and he has represented a source of hope for pro-Europeans. His vision is comprehensive and his proposals do tackle the main issues facing the EU discussed earlier. However, all the praises cannot hide how lukewarm the responses from Member States were and how, before Covid-19 struck, they took small steps rather than the giant leaps he suggested. The Mesenberg declaration (2018) that diluted his bold ambitions for the Eurozone, removing the idea of a parliament and a finance minister and shrinking the budget he envisioned, is a good illustration. Part of the problem is a lack of enthusiasm for further integration amongst his fellow leaders, with Macron not having any leverage to wield. The other part is Macron's inability to build coalitions. Taken together, it is argued that Macron has been a brilliant architect but a poor brick layer.

To start with, Macron has had to face a distinct lack of enthusiasm, with many Member States opposed to big plans and happy to muddle through for fear of a backlash from Eurosceptic forces at the national level. It is true that national leaders have all contributed to the debate on the future of the EU and "have demonstrated a high degree of convergence in areas such as social policy, climate change and energy, and the single market" (Dinan, 2019: 502). It is also true that "calls for less Europe are rare" (Dinan, 2019: 503), except from a few countries such as Poland. However, calls for more Europe have been very much muted and many states have contributed to a process of disintegration, not by renouncing formal EU commitments but through "deteriorating compliance with EU law" (Vollaard 2018). The thirst for deeper integration is therefore not shared by Macron's partners. Thus, the recent coalition builder report shows how hard it is for Macron, summarising his isolation with the pithy comment that "put bluntly, French respondents do not care about the same things that concern most other Europeans" (Puglierin and Franke 2020a: 16).

A good illustration is provided by Macron's plan for the Eurozone. His proposals are part of a necessary and crucial debate, as it is not a secret that it needs to be reformed to tackle its original sin, i.e. the imbalance between a single monetary policy and national fiscal policies without any solidarity mechanisms, as well as shielding it from any future asymmetric shock, as highlighted by the large number of reports produced over the years as well as numerous contributions by scholars. Despite a range of options put forward, such as full fiscal union, debt relief, periodic fiscal transfers, rainyday funds, common unemployment insurance, or debt sharing, leaders have opted "only for half-measures that prevent the euro's collapse but fix none of its fundamental problems" (Copelovitch 2020). Macron's proposals, whilst not new in themselves, are important because they give a political urgency to 
the debate that has been rambling on for years. However, he did not go very far, as illustrated by the Mesenberg declaration, and the strong resistance both from Germany and the new Hanseatic league. Neo-functionalism and liberal inter-governmentalism provide a good lens to explain his lack of results. At the height of the Eurocrisis, functional pressures in the shape of negative spillover dynamics, should the Eurozone break up, and prohibitive status quo costs, explain why France and other like-minded states prevailed over Germany and succeeded in pushing for risk mutualization and the bail-out of insolvent member states (Schild 2020). Germany was forced to make concessions but only as long as the break-up of the zone was a real threat, i.e. when it had more to lose if nothing was done (Schild 2020). Macron came along at a time when the worst of the Euro-crisis was over and the Eurozone economies were growing again. The functional pressure on Germany was no longer there, which enabled it to water down his ambitious proposals. As a result, some of his other proposals ended up diluted too. Thus, considering the impact the social fallout from the Eurocrisis has had on turning public attitude against the EU (Braun and Tausendpfund 2014), Macron is right to focus on a more social Europe and solidarity. However, his proposals will not succeed until the eurozone is fixed but he does not have the leverage and functional pressure to convince Member States opposed to further integration of the zone.

Europe as a balancing power is another good illustration. Macron's vision is clear, heavily influenced by Realism, with great power rivalry squeezing Europe at its heart. The need for a stronger Europe in both defence and foreign policy has been underlined by many scholars and has been called for by EU institutions and other Member States too. Thus, Macron and Merkel have often talked about the need for Europeans to play a "greater role on the global stage if they want to avoid being torn apart by great power competition" (Puglierin and Franke 2020b). Thus, President Ursula von der Leyen set out to establish a geopolitical Commission. It does make sense for the EU to speak with one voice as far as possible in the face of great power competition. However, his very detailed vision is not shared by all the member states and neither is the need for further integration. According to the 2020 coalition builder report, only France, Cyprus and Greece have defence in their top 5 priorities (Busse et al. 2020). Whereas it ranks first for France it is a lowly 14th for Germany. The situation is similar when it comes to foreign policy. Whereas foreign policy is in the top 5 priorities for France, it is only in eighth place for the EU 27 overall, and even lower for Southern states, who do not tend to prioritise foreign policy (Puglierin and Franke 2020a). As a result, the type of integration Macron is pushing for has been met by a lack of urgency and priority by the other states, and he does not have the leverage to move his partners who "are still geopolitical navel-gazers" (Puglierin and Franke 2020a: 26). 
To make matter worse, Macron has been unable to build coalitions to overcome the lack of enthusiasm for deeper integration. In a union of 27 countries, a vision is not enough in itself. Any European leader needs to be able to work with others, which Macron has been unable to engineer. As Wright explains (2020: 14), "some EU leaders have complained of Macron's unilateral approach and his inability, as they see it, to compromise." The lukewarm response to his proposals has thus been ascribed to the French president's 'arrogant' manner as much as to the desirability of his suggestions, with many member states unhappy with his style. In addition, his views on defence and foreign policy have proved highly divisive, which hindered his attempt to build a coalition of willing states. Thus, his comment about NATO being brain dead (Macron 2019b) created widespread alarm and hostility in EU capitals. Many states, in particular in Central and Eastern Europe, are wary of anything that might weaken NATO and undermine its cohesion, seeing the US presence in Europe as life insurance. Similarly, Macron's argument about the necessity to engage with Russia was soundly criticised by CEE countries as they see it as the main threat to their security and met with dismay by Germany. As a result, in the 2020 Coalition explorer, France was seen as the "third most disappointing country - after Hungary and Poland" (Puglierin and Franke 2020a: 11) and until Covid-19 struck, he became increasingly isolated. Macron may have worked hard to get his message across but his style has hampered his ability to convince his partners.

Part of his inability to build coalitions has been his misreading of Germany. He failed to see that Merkel had been weakened domestically by the results of the 2017 elections and had to contend with a rising Eurosceptic party, the AfD. Merkel did contribute to the future of Europe debate, with speeches echoing some of Macron's calls for EU reforms (Dinan 2019) but she never went as far as the French president. He did not see that it makes sense from Germany's point of view. As Puglierin and Franke explain, "as it has weathered the crises of the past decade far better than most member states, Germany feels no sense of urgency to make radical changes to the EU's institutional set-up" (2020a: 8). Whereas Macron wanted to shake up the status quo, the Merkel government has maintained what Janning (2019) called its "ultra-pragmatic, status quominded course of non-action". As a result, his inability to move Germany, which remains the EU's centre of gravity, has meant no significant advances at the EU level, until Covid-19 changed the functional pressure on Germany, leading to "deep frustration and disappointment with Germany" (Puglierin and Franke 2020a: 30). Macron did try to pivot away from Germany and forge new alliances. However, he failed to read the situation, such as the mistrust towards fiscal transfers by countries like the Netherlands, CEE countries' security concerns towards Russia or Southern countries not sharing his priorities. 
Macron failed to realise that many states are more interested in the status quo than deeper integration in the scale he envisioned, and are irritated by his style. He might have succeeded in putting on the agenda crucial issues for the future of the EU but his difficulties in building coalitions has meant that however well thought-out his vision is it has remained to a large extent rhetorical.

\section{European sovereignty and democracy}

Macron's concept of European sovereignty is very important and has been embraced by many pro-EU figures. For example, Juncker called his 2018 state of the union speech "the hour of European sovereignty", and Merkel talked about the EU taking fate into its own hands. This concept expresses the sense "that the EU ought to itself be a great power, as opposed to the 'normative power' it once aspired to be" (Kundnani 2020). There is indeed functional external pressure that is pushing Europeans towards forming a bigger unit to be able to stand up to great power politics or to the pressures from globalisation. However, his attempt to respond to "enduring and politically flammable concerns over national sovereignty" (Zeitlin et al. 2019: 969) is deeply problematic because his failure to discuss the nexus between sovereignty and democracy leaves far too many questions unanswered. Macron conflates sovereignty with being powerful, as evidenced by all his proposals being explained by the need to make the EU a power that can act. This cannot be a meaningful definition of sovereignty as it leaves aside too many crucial questions: (1) If European sovereignty is about being powerful relative to other countries, what does it mean about power within the EU? As Kundnani (2020) asked, "who exactly is sovereign in a sovereign Europe?" (2) What is the theoretical underpinning of this sovereignty? As discussed earlier, the debate over the EU democratic deficit pits various conceptions based on radically different theories and normative stances. What type of sovereignty is Macron really putting forward? (3) What does European sovereignty mean for democracy at the EU level? Macron does talk about putting citizens and democracy at the heart of the EU, and he does offer some proposals such as democratic conventions and transnational lists. However, how citizens are going to be involved is not clear. How is the European political space he is calling for going to be created? How is it going to be reconciled with his call for more EU agencies? Are they not going to "further alienate the citizens trust in democratic procedures" (Navratil 2019:9) unless citizens have power over them?

The key challenge to the EU is how to create "spaces for contestability at supranational level" (Nicoli 2020: 26), in order to boost input legitimacy and channel political opposition demanding a radically different EU within the system instead of against it. Unless leadership and policy direction 
are contestable, it is far too easy for populist parties to claim to be the true representatives of the people and pointing out how the EU is taking powers from national representations. Macron's proposals fell far too short on this crucial issue because he does not provide a clear definition of what sovereignty is, beyond power, and a clear link between sovereignty and democracy.

\section{Differentiated integration as a way forward?}

Macron is offering an important contribution to the idea of Differentiated Integration (DI), i.e. a set of strategies through which the heterogeneity of preferences among Member States is reconciled with demands for further integration (Stubb 1996). Macron's proposal for DI is aimed at reinvigorating the integration process by allowing a cluster of states to forge ahead. Far from being a new concept, it has been at the heart of key integration advances, such as Schengen or the Euro and a range of DI has been put forward in the scholarship, such as two-speed (core-periphery), multi-speed, a Europe of different unions, a Europe of different clubs beyond the single market, or a Europe completely à la carte (Schmidt 2019b).

DI remains contested, with various arguments put forward against it: creating second class status, with states opting out feeling excluded, leading to resentment; weakening solidarity between Member States; creating undue pressure on states to join at a later stage; threatening the overall cohesion of the EU as well as the unity of its legal order and adding complexity to an already complex entity; undermining the creation of a European demos through creating differentiated individual rights and obligations; being a slippery slope towards disintegration, with differentiation leading to increasing divergence up to the point of withdrawal. However, considering the increase of EU competences and the diversity of its membership it can be regarded as a natural feature of regional integration. DI does not have be seen as a sign of crisis but as a variant of integration because it allows it to carry on whilst respecting the diverse integration preferences of members states (Schimmelfennig 2018). Rather than a path to disintegration, it can therefore be seen as a solution to integrate into new areas because, without it, "integration agreements would not go beyond the preference of the most status quo-oriented member state" (Schimmelfennig 2018: 1158).

Macron has succeeded in avoiding the main pitfalls of DI from a proEuropean lens by rejecting a full à la carte Europe, which would mean no overall vision and cohesion, with everyone picking what they want. This would generate undue positive and negative externalities for both the integrated and the non-integrated countries (Martill 2020). For example, DI would not work when it comes to migration, as the cherry-picking would disadvantage insiders 
too much. Similarly, it would not work for the Eurozone, as the creation, for example, of a northern and southern zone would have prohibitive costs. The rule of law, as a fundamental value of the EU, should also not be dealt with by DI, otherwise its whole ethos would collapse.Overall, it has been shown that DI works best to boost integration into new policies (Martill 2020). In this respect, Macron's proposal is good as he stated that the rule of law was not negotiable and he envisions integration into new areas. Considering that any radical changes to the EU would require a fundamental constitutional showdown that leaders are not ready to face, the DI put forward by Macron is a useful tool to push integration forward and avoid the biggest danger for the EU, differentiated disintegration (Webber 2013).

However, Macron's enthusiasm for DI hides an important flaw, the nonspecification of what kind of EU it entails. DI makes sense if federalism is not sought. Indeed, if the EU is seen through a statist lens, then DI is an aberration, as a state requires clearly demarcated borders and policy areas. DI makes sense if the benchmark for the EU is demoicracy but it does not if the European project is aimed at creating a European demos. Demoicracy underpins DI, as it allows citizens in each member states to decide what they want to participate in or not, thereby granting each sovereign nation "the sovereign right to choose the level of integration that matches its identity and preferences" (Lord 2015: 792). It could be seen as a good compromise to deepen integration without losing more countries but normatively speaking, Macron is building a certain type of EU without saying so. His inability to clearly articulate the content of his concept of European sovereignty and democracy already seen earlier is at play again and has to be seen as the real blindspot of his vision.

\section{Conclusion: lessons to be drawn}

A decade of polycrisis has led scholars to ponder over the future of the EU, pinpointing different possible scenarios: full disintegration; partial disintegration with some areas renationalised; muddling through crises with piecemeal adjustments; functional federalism, with more integration in defined fields, whether supranational or intergovernmental; differentiated integration; federal Europe (Jones 2018). The EU Commission white paper on the future of the EU, for example, whilst not envisioning the end of the EU, provided five possible futures: status-quo with incremental changes; nothing but the single market; differentiated integration; focusing on fewer policy areas; deepening integration together (EU Commission 2017). In this context, Macron's commitment to the European project has led him to reinvigorate the debate through a comprehensive vision for the future based on the construction of an 
imagined community protected by a strong European sovereignty. However, his vision has flaws and has been met with scepticism, sluggish responses and, until covid-19 struck, no major reforms.

A few lessons should be drawn from a pro-European point of view. To start with, ambition alone is not enough, patience and building coalitions are key. Chopin argued in 2018 that "Emmanuel Macron has to find the right balance between the will to exercise political (co)-leadership in the Union, and the defence of realistic ambitions amongst France's European partners" (p.8). However, his ambitions for the EU stumbled on a political environment that are not conducive to deeper integration in most member states, due to the pressure of Eurosceptic parties, and on his style perceived as too revolutionary and arrogant. Voluntarism, therefore, has to be combined with a more patient and less divisive approach in order to create coalitions of the willing. Second, asymmetries cannot be wished away because "no matter how strong and full of ideas a French leader might be, France will always come second to Germany" (Puglierin and Franke 2020a:15). Macron might be correct in his assessment that the Eurozone has to be sorted out but speeches alone will not be enough, as the asymmetric power held by Germany can only be circumvented by changing its cost-benefit analysis. Germany's reaction to Covid-19 and its willingness to break taboos in the EU's recovery plan prove that it does react to functional pressures and path dependencies. Working on publicising their outcomes should the Eurozone remains the same and building coalitions to change asymmetries have more chances of success than invoking a nebulous notion of solidarity. Focusing on asymmetries and path dependencies should therefore become a priority. Third, any pro-European has to come to grip with sovereignty and democracy. Macron's vision is faulty precisely because he did not specify their underpinning. Invoking them as weapons against Euroscepticism is meaningless unless citizens understand and agree to what they mean in practice. Otherwise, they will remain empty concepts easily dismantled by opponents to the EU. Fourth, politicising the EU the way Macron has done is important. Politicisation does not have to be feared as it is good for democratic legitimacy. As Schmidt shows, "greater EU-level public deliberation and debate, however contentious, is in and of itself politically legitimating." (2019a: 1032) His injunction to talk more about Europe is therefore important. However, creating an imagined community based on an exclusionary discourse and on potential securitisation moves and failing to tackle the nexus between sovereignty and democracy leaves Macron open to criticisms from both pro-European and Eurosceptic forces. A clear articulation of what sovereignty and democracy are at the EU level has to be a priority, along with seeking its approval by citizens.

All in all, Macron has offered hope and a renewed dynamism. He has shown that a change of narrative is possible, that pro-Europeans should stop 
being on the defensive and not be afraid of talking about Europe. He is correct in his assessment of the urgent need to explain what the EU brings and he has provided a break from the negative politicisation of the EU driven by Eurosceptics. He is correct in not wanting to leave the European question in their hands. However, in addition to his limited ability so far to build coalitions of the willing, his vision is fundamentally undermined by his failure to explain what underpins his call for European sovereignty and where democracy stands, which is crucial to convince citizens that the EU is not a threat and move them away from Euroscepticism. Unless this blindspot is dealt with vigorously and openly Macron will be remembered as a struggling visionary and further European integration will be hindered. 


\section{References:}

Allison 2017: G. Allison, Destined for war: can America and China escape Thucydides's trap? (Boston, 2017).

Anderson 1991: B. Anderson, Imagined communities: Reflections on the origin and spread of nationalism (New York, 1991).

Armigeon et al. 2016: K. Armingeon, K. Guthmann, and D. Weisstanner, "How the Euro divides the union: the effect of economic adjustment on support for democracy in Europe" in Socio-Economic Review, 14(1) (2016), pp. 1-26.

Baker-Beall 2009: C. Baker-Beall, "The Discursive Construction of EU Counter-Terrorism Policy: Writing the 'Migrant Other', Securitisation and Control" in Journal of Contemporary European Research, 5(2) (2009), pp.188-206.

Beetz 2019: J.P. Beetz, "Safeguarding, shifting, splitting or sharing? Conflicting conceptions of popular sovereignty in the EU-polity" in Journal of European Integration, 41(7) (2019), pp. 937-953.

Bigo 2002: D. Bigo, "Security and immigration: Toward a critique of the Governmentality of Unease" in Alternatives: Global, Local, Political, 27(1) (2002), pp. 63-92.

Billig 1995: M. Billing, Banal nationalism (London, 1995).

Braun and Tausendpfund 2014: D. Braun, D. and M. Tausendpfund, "The Impact of the Euro Crisis on Citizens' Support for the European Union" in Journal of European Integration, 36(3) (2014), pp.231-245.

Bremner 2017: C. Bremner, "Only I can make France great again, says Le Pen" in The Times, February 17 2017, https://www.thetimes.co.uk/article/onlyi-can-make-france-great-again-says-le-pen-0grpnbhh9

Busse et al. 2020: C. Busse, U.E. Franke, R. Loss, J. Puglierin, M. Riedel and P. Zerka, "EU Coalition Explorer" in ECFR, July 2020, https://www.ecfr. eu/eucoalitionexplorer

Chopin 2018: T. Chopin, "Emmanuel Macron, France and Europe "France is back in Europe": on which terms?" in Robert Schuman Foundation, May 14 2018, https://www.robert-schuman.eu/en/european-issues/0473emmanuel-macron-france-and-europe-france-is-back-in-europe-onwhich-terms

Copelovitch 2020: M. Copelovitch, "None of the above is no longer an option for the Eurozone" in LSE, April 21 2020, https://blogs.lse.ac.uk/ europpblog/2020/04/21/none-of-the-above-is-no-longer-an-option-forthe-eurozone/ 
Craig 2019: P. Craig, "The EU, Democracy and Institutional Structure: Past, Present and Future" in W. Heusel and J.P. Rageade, coord.: The Authority of EU Law, Do We Still Believe in It? (New York, 2019).

De Wilde and Lorde 2016: P. De Wilde and C. Lord, "Assessing actuallyexisting trajectories of EU politicisation", in West European Politics, 39(1) (2016), pp.145-163.

Dinan 2019: D. Dinan, "Debating Europe's future" in Irish Political Studies, 34(4) (2019), pp.490-506.

Easton 1975: D. Easton, David, "A reassessment of the concept of political support" in British Journal of Political Science, 5 (1975), pp. 435-457.

Egeberg 2015: M. Egeberg, "EU Administration: Center Formation and Multilevelness", in M.W. Bauer and J. Trondal, coord.: The Palgrave Handbook of the European Administrative System. (London: 2015).

EU Commission 2017: EU Commission, "White paper on the future of the EU" in europa.eu, (2017), https://ec.europa.eu/commission/future-europe/ white-paper-future-europe/white-paper-future-europe-five-scenarios en

Euractiv 2018: Euractiv, "Macron, lauréat du prix Charlemagne", May 8 2918, https://www.euractiv.fr/section/avenir-de-1-ue/news/macron-getscharlemagne-prize-on-first-anniversary-in-office/

European Council 2019: European Council, "EU action to strengthen rulesbased multilateralism", in consilium.europa.eu, (2019), https:/www. consilium.europa.eu/media/39791/st10341-en19.pdf

Fägersten and von Sydow 2019: B. Fägersten and G. von Sydow, G, "Introduction" in B. Fägersten and G. von Sydow, coord.: Perspective on the future of the EU. (Stockholm, 2019).

Flockhart 2016: T. Flockhart, "The coming multi-order world", in Contemporary Security Policy, 37(1) (2016), pp.3-30.

Føllesdal and Hix 2006: A. Føllesdal and S. Hix, "Why there is a democratic deficit in the EU: a response to Majone and Moravcsik" in JCMS, 44(3) (2006), pp. 533-562.

Hall 1996: S. Hall, "Introduction: Who needs 'identity'?” in S. Hall and P. Du Gay, P., coord.: Questions of cultural identity (London, 1996).

Hellman et al. 2014: G. Hellman, B. Herborth, G. Schlag and C. Weber, "The west: A securitising community?" in Journal of International Relations and Development, 17 (3) (2014), pp. 367-396.

Hodson and Puetter 2019: D. Hodson and U. Puetter, "The European Union in disequilibrium: new intergovernmentalism, postfunctionalism and integration theory in the post-Maastricht period" in Journal of European Public Policy, 26(8) (2019),pp.1153-1171. 
Hooghe and Marks 2019: L. Hooghe and G. Marks, "Grand theories of European integration in the twenty-first century" in Journal of European Public Policy, 26(8) (2019), pp. 1113-1133.

Hooghe and Marks 2009: L. Hooghe and G. Marks, “A Postfunctionalist Theory of European Integration: From Permissive Consensus to Constraining Dissensus", in British Journal of Political Sciences, 39(1) (2009), pp. $1-23$.

Hutter and Kriesi 2019: S. Hutter and H. Kriesi, "Politicizing Europe in Times of Crisis" in Journal of European Public Policy, 26 (7) (2019), pp. 9961017.

Janning 2019: J. Janning, "Paradigm lost: A post-Merkel Germany in a postKohl Europe" in ECFR, November 27 2019, https://www.ecfr.eu/article/ commentary_paradigm_lost a post_merkel_germany in_a post kohl europe

Jervis et al. 2018: R. Jervis, F.J. Gavin, J. Rovner and D. Labrosse, Chaos in the Liberal Order: The Trump Presidency and International Politics in the Twenty-First Century (New York, 2018).

Jones 2018: E. Jones, E. "Towards a theory of disintegration" in Journal of European Public Policy, 25(3) (1998), pp. 440-51.

Juncker 2016: J.C. Juncker, "State of the Union 2016. Towards a better Europe" in statewatch.org, (2016), https://www.statewatch.org/media/documents/ news/2016/sep/eu-com-state-of-union-2016.pdf

Kenealy 2019: D. Kenealy, "The EU's Foreign, Security and Defence Policies in an Unstable World" in K. Hughes, coord.: The Future of Europe: Disruption, Continuity and Change (Scottish Centre on European Relations, 2019).

Kundnani 2020: H. Kudnani, "Europe's sovereignty conundrum" in Berlin Policy Journal, May 13 2020, https://berlinpolicyjournal.com/europessovereignty-conundrum/

Kundnani 2018: H. Kudnani, "The troubling transformation of the EU", in LSE, March 28 2018, https://blogs.lse.ac.uk/europpblog/2018/03/28/thetroubling-transformation-of-the-eu/

Kupchan 1998: C.A. Kupchan, "After Pax Americana: Benign Power, Regional Integration, and the Sources of a Stable Multipolarity" in International Security, 23(2) (1998), pp. 40-79.

Laffan 2019: B. Laffan, "Future scenarios of the European Union. Oxford Research", Oxford Research, (2019), https://oxfordre.com/ politics/view/10.1093/acrefore/9780190228637.001.0001/acrefore$\underline{9780190228637-\mathrm{e}-1493}$ 
Lindberg and Scheingold 1970: N. Lindberg and S. Scheingold, S. Europe's Would-Be Polity: Patterns of Change in the European Community (Englewood Cliffs, 1970).

Lord 2015: C. Lord, "Utopia or dystopia? Towards a normative analysis of differentiated integration" in Journal of European public policy, 22(6) (2015), pp. 783-798.

Macron 2017a: E. Macron, "Speech by the President of the French Republic (Athens, 7 September 2017)" in diplomatie.gouv.fr, (2017), https:// www.diplomatie.gouv.fr/en/french-foreign-policy/europe/news/article/ european-union-speech-by-the-president-of-the-french-republicathens-07-09-17

Macron 2017b: E. Macron, "Initiative for Europe in Ouest France, (2017), http://international.blogs.ouest-france.fr/archive/2017/09/29/macronsorbonne-verbatim-europe-18583.html

Macron 2018a: E. Macron, "Speech by Emmanuel Macron, President of the Republic at European Parliament" in elysee.fr, 2018, https://www. elysee.fr/emmanuel-macron/2018/04/17/speech-by-emmanuel-macronpresident-of-the-republic-at-european-parliament.en

Macron 2018b: E. Macron, "Speech by M. Emmanuel Macron, President of the Republic, on receiving the Charlemagne Prize" in elysee.fr, (2018), https:// www.elysee.fr/emmanuel-macron/2018/05/10/speech-by-m-emmanuelmacron-president-of-the-republic-on-receiving-the-charlemagne-prize-1. en

Macron 2019a: E. Macron, E, "For European renewal", in elysée.fr, (2019), https://www.elysee.fr/emmanuel-macron/2019/03/04/for-europeanrenewal.en

Macron 2019b: E. Macron, "Emmanuel Macron in his own words" in The economist, November 7 2019, https:/www.economist.com/ europe/2019/11/07/emmanuel-macron-in-his-own-words-english

Macron 2020a: E. Macron, "President Emmanuel Macron's speech at Jaguellonne University, Krakow" in elysee.fr, (2020), Retrieved from https://www.elysee.fr/en/emmanuel-macron/2020/02/05/presidentemmanuel-macrons-speech-at-jaguellonne-university-krakow

Macron 2020b: E. Macron, "Plus que jamais nous avons besoin d'Europe. Message du Président Emmanuel Macron sur le Brexit" in elysée.fr, (2020), https://www.elysee.fr/emmanuel-macron/2020/01/31/plus-quejamais-nous-avons-besoin-deurope-message-du-president-emmanuelmacron-sur-le-brexit 
Majone 2014: G. Majone, "From regulatory state to a democratic default" in Journal of Common Market Studies, 52(6) (2014), pp. 1216-1223.

Martill and Brinke 2020: B. Martill and T. Brinke, "Europe in a multipolar world" in LSE, (2020), https://www.lse.ac.uk/ideas/Assets/Documents/ updates/LSE-IDEAS-Europe-in-a-Multipolar-World.pdf

Martill 2020: B. Martill, "Brexit and Differentiated Integration: The Politics of Difference" in Dahrendorf Forum IV Working Paper No. 18, 26 May 2020 .

Mearsheimer 1994: J. Mearsheimer, "The False Promise of International Institutions" in International Security, 19(3) (1994), pp. 5-49.

Mesenberg 2018: Mesenberg declaration, in diplomatie.gouv.fr, (2018), https:// www.diplomatie.gouv.fr/en/country-files/germany/events/article/europefranco-german-declaration-19-06-18

Moravcsik 2002: A. Moravcsik, "Reassessing legitimacy in the European Union” in JCMS, 40(4) (2002), pp. 603-624.

Navratil 2019: M. Navratil, "Taking Stock on Future of the EU According to Macron: Perspective from the V4" in Europeum policy paper, (2019), https://www.europeum.org/domains/europeum.org/www/data/articles/ policy-paper-en-2.pdf

Nicoli 2020: F. Nicoli, "Democratic Deficit and Its Counter-Movements: The Eurocentric-Eurosceptic Divide in Times of Functional Legitimacy" in M. Baldassari, E. Castelli, M. Truffelli and G. Vezzani, coord.: AntiEuropeanism. Critical Perspectives Towards the European Union (New York, 2020).

Puglierin and Franke 2020a: J. Puglierin, and U.E. Franke, "The big engine that might: how France and Germany can build a geopolitical Europe" in ECFR, (2020), https://www.ecfr.eu/publications/summary/the big engine that might how france and germany can build a geopolitical e

Puglierin and Franke 2020b: J. Puglierin, and U.E. Franke, "Why Europe needs a recovery plan for strategic autonomy" in ECFR, August 3 2020, https:// www.ecfr.eu/article/commentary_why_europe_needs_a_recovery_plan_ for_strategic_autonomy

Scharpf 2013: F.W. Scharpf, "Political Legitimacy in a Non-Optimal Currency Area" in MPIfG Discussion Paper, No. 13/15, Max Planck Institute for the Study of Societies, (2013).

Scharpf 1999: F. Scharpf, Governing in Europe: Effective and Democratic? (Oxford, 1999).

Schild 2020: J. Schild, "EMU's asymmetries and asymmetries in German and French influence on EMU governance reforms" in Journal of European Integration, 42(3) (2020), pp. 449-464. 
Schimmelfennig 2019: F. Schimmelfennig, "Getting around no: how governments react to negative EU referendums" in Journal of European Public Policy, 26(7) (2019), pp. 1056-1074.

Schimmelfennig 2018: F. Schimmelfennig, "Brexit: differentiated disintegration in the European Union" in Journal of European Public Policy, 25(8) (2018), pp. 1154-1173.

Schmidt 2019a: V. Schmidt, "Politicization in the EU: between national politics and EU political dynamics" in Journal of European Public Policy, 26(7) (2019), pp.1018-1036.

Schmidt 2019b: V. Schmidt, "The future of differentiated integration: a 'softcore,' multi-clustered Europe of overlapping policy communities" in Comparative European Politics, 17 (2019), pp.294-315.

Stubb 1996: A. Stubb, "A categorization of differentiated integration" in Journal of Common Market Studies, 34(2) (1996), pp. 283-295.

Svendsen 2019: O. Svendsen, "Brexit and the future of EU defence: a practice approach to differentiated defence integration" in Journal of European Integration, 41(8) (2019), pp. 993-1007.

Vollard 2018: H. Vollaard, "How the European Union falls apart" in LSE, July 2 2018, https://blogs.lse.ac.uk/europpblog/2018/07/02/how-the-europeanunion-falls-apart/

Webber 2013: D. Webber, "How likely is it that the European Union will disintegrate? A critical analysis of competing theoretical perspectives" in European Journal of International Relations, 20(2) (2013), pp. 341-365.

Wright 2020: G. Wright, "France" in A. Menon, coord.: The future of the EU: new perspectives, 2020, https://ukandeu.ac.uk/wp-content/uploads/2020/03/ Future-of-the-EU-report.pdf

Zeitlin et al. 2019: J. Zeitlin, F. Nicoli and B. Laffan (2019), "Introduction: the European Union beyond the polycrisis? Integration and politicization in an age of shifting cleavages" in Journal of European Public Policy, 26(7) (2019), pp. 963-976. 
